\title{
The Effect of Television Advertising in United States Elections
}

\author{
JOHN SIDES Vanderbilt University, United States \\ LYNN VAVRECK University of California, Los Angeles, United States \\ CHRISTOPHER WARSHAW George Washington University, United States
}

\begin{abstract}
$W$
e provide a comprehensive assessment of the influence of television advertising on United States election outcomes from 2000-2018. We expand on previous research by including presidential, Senate, House, gubernatorial, Attorney General, and state Treasurer elections and using both difference-in-differences and border-discontinuity research designs to help identify the causal effect of advertising. We find that televised broadcast campaign advertising matters up and down the ballot, but it has much larger effects in down-ballot elections than in presidential elections. Using survey and voter registration data from multiple election cycles, we also show that the primary mechanism for ad effects is persuasion, not the mobilization of partisans. Our results have implications for the study of campaigns and elections as well as voter decision making and information processing.
\end{abstract}

$\mathbf{H}$ ow much does televised campaign advertising affect election outcomes in the United States? This has been a pertinent question since the first televised advertisements were aired during a 1950 Connecticut Senate election and then by President Dwight Eisenhower's 1952 campaign (Benoit 2018). Answering this question helps illuminate the motivations behind voting behavior, the influence of mass communication on the electorate, and how much candidates' resources and messages can help them win elections. Moreover, the aggregate effect of televised advertising may determine the actual winner in at least some races, thereby affecting the composition of government and the direction of public policy.

Political campaigns spend a great deal of money on television advertising. According to Fowler, Ridout, and Franz (2016), over $\$ 2.75$ billion was spent to air over 4.25 million ads in the 2015-2016 election cycle. This includes about 1 million airings in the presidential race, 1 million airings in Senate races, 620,000 airings in House races, and 1.25 million airings in other races at the state and local levels. Spending on television advertising constitutes about $45 \%$ of a typical congressional campaign's budget (Jacobson and Carson 2019).

Research on televised political advertising has made significant progress in estimating its influence on voting behavior (for overviews, see Fowler, Franz, and Rideout 2016; Goldstein and Ridout 2004; Jacobson 2015). Studies have found associations between television

John Sides (D), William R. Kenan, Jr. Professor, Department of Political Science, Vanderbilt University, United States, john.m.sides@vanderbilt.edu.

Lynn Vavreck (D), Marvin Hoffenberg Professor of American Politics, Department of Political Science, University of California, Los Angeles, United States, lvavreck@ucla.edu.

Christopher Warshaw (iD, Associate Professor, Department of Political Science, George Washington University, United States, warshaw@gwu.edu.

Received: December 21, 2020; revised: June 24, 2021; accepted: August 25, 2021. First published online: November 2, 2021. advertising and individual vote intentions, aggregate vote shares, or both (e.g., Huber and Arceneaux 2007; Rideout and Franz 2011; Sides and Vavreck 2013; Spenkuch and Toniatti 2018). In presidential general elections, the persuasive influence of television advertising appears to be larger than that of other electioneering such as canvassing or mail, the influence of which is quite small, even zero (Kalla and Broockman 2018).

But there are significant limitations to what we know about the effects of televised campaign advertising on election outcomes. Most importantly, the extant literature is almost entirely focused on presidential general elections (e.g., Gordon and Hartmann 2013; Johnston, Hagen, and Jamieson 2004; Shaw 2006; Sides and Vavreck 2013; Sides, Tesler, and Vavreck 2018; Spenkuch and Toniatti 2018). Only a few studies have examined advertising effects in Senate elections (Fowler, Ridout, and Franz 2016; Goldstein and Freedman 2000; Jacobson 1975; Ridout and Franz 2011; Wang, Lewis, and Schweidel 2018) or House elections (Hill et al. 2013; Jacobson 1975). ${ }^{1}$ Just two studies have examined gubernatorial elections and both focus on survey-based vote intentions rather than election results (Gerber et al. 2011; Hill et al. 2013). To our knowledge, there has been no published research on the effect of advertising in down-ballot state-level races, such as elections for state Attorney General. And, most importantly, no study has used a comparable, credible research design to study advertising effects across multiple levels of office. The

\footnotetext{
${ }^{1}$ Scholars have investigated the tone of campaigning in Senate elections and its possible effects on election outcomes (Lau and Pomper 2004) and how voter decision making depends on the "intensity of Senate campaigns" (Kahn and Kenney 1999; Westlye 1991), which are related to but distinct from our focus. Studies of US House elections focus mainly on candidate spending as a proxy for specific forms of campaigning such as advertising (e.g., Green and Krasno 1988; Jacobson 1978). Only occasionally have scholars tried to isolate the effects of House electioneering activities (Ansolabehere and Gerber 1994; Jacobson 1975; Schuster 2020).
} 
most relevant prior studies compare presidential and Senate elections (Fowler, Ridout, and Franz 2016; Jacobson 1975; Ridout and Franz 2011) and find that advertising in Senate elections appears to have larger effects on election outcomes than does advertising in presidential elections. This paucity of studies illustrates the conclusion of Kalla and Broockman (2018), who, after canvassing the available experiments on persuasion in general election campaigns, argue that "more evidence" on televised advertising "would clearly be welcome" (163). We seek to provide that evidence.

Campaign advertisements provide information to voters that may change the balance of considerations they hold about candidates in a given contest. As the balance shifts, citizens may change their views of the candidates (persuasion) or change their mind about whether to vote at all (mobilization). If advertising affects election outcomes mainly through persuasion at the individual level, it should have larger effects in down-ballot races than in presidential races. This is because voters know less and have weaker opinions about down-ballot candidates relative to presidential candidates. But if advertising works mainly through mobilization, potentially altering the partisan composition of the electorate, voters' decisions to stay home or turn out should affect all races on the ballot similarly. If so, there should be little heterogeneity across offices in the effect of ads on election outcomes.

We test these expectations by examining the effects of broadcast television advertising on election outcomes in the five presidential elections from 2000 to 2018 and also in 331 US Senate elections, 226 gubernatorial elections, 3,859 US House elections, and 237 other state-level elections during this period. In total, we examine over 4,500 different races. To address the possibility that campaigns may place ads in media markets where they expect to do well (Erikson and Tedin 2019, 250), we employ research designs that strengthen the causal interpretation of our findings, including time-series cross-sectional models with a difference-in-differences design (Angrist and Pischke 2009) and a border-discontinuity design (Spenkuch and Toniatti 2018).

We find that the effect of ad airings is much larger in down-ballot elections than in presidential elections. The apparent effect of an individual airing is two to four times larger in gubernatorial, US House, and US Senate elections and 10 to 19 times larger in other statewide races, compared with presidential elections.

We also provide evidence that persuasion is the primary mechanism through which these differing effects of advertising emerge. Drawing on surveys of hundreds of thousands of voters across eight election cycles, we show that voters have less information and weaker opinions about the candidates in down-ballot races than about presidential candidates and that in these down-ballot races television advertising is more strongly associated with voters' knowledge of the candidates, evaluations of the candidates, and ideological congruence with the candidates than it is in presidential races. By contrast, we find less evidence for another possible mechanism: that television advertising affects election outcomes by changing the partisan composition of the electorate. Drawing on administrative data from six different election cycles, we show that advertising is not consistently associated with the relative turnout of Democrats and Republicans. Moreover, we find that ads for one race do not substantially "spill over" and affect outcomes at another level of office, as would be true if advertising altered the partisan composition of the voters in any election year.

Our paper has several implications for the study of voting behavior and elections. Despite increasing partisan loyalty among American voters, some voters still respond to television advertising. This is particularly true in down-ballot elections. Indeed, while television advertising is likely to swing only very close presidential elections, infusions of television advertising could swing a larger number of close down-ballot elections. Thus, the effort that candidates, political parties, and outside groups invest in raising money for, producing, and airing television advertising pays dividends. Mass communication in electoral campaigns matters, even in a more polarized electorate.

\section{THEORETICAL MOTIVATION}

Does television advertising in US elections affect election outcomes? And should its effect vary across levels of office? Drawing on literatures in psychology, political science, economics, and political communication, we assemble a set of expectations for both questions.

Campaign advertising can persuade voters if it provides novel information that affects their attitudes about one or both candidates. Prior research on attitude change shows that people can be susceptible to persuasion, but that there are many obstacles to changing someone's mind (e.g., DellaVigna and Gentzkow 2010; Petty, Priester, and Wegener 2014; Sears and Kosterman 1994). This well-established idea is central to theories of information processing in political science. For one, Zaller (1992) argues that attitude change in response to information is conditional on partisanship and other predispositions ("partisan resistance") as well as the number of existing considerations that someone has about an attitude object ("inertial resistance"). For another, Lodge and Taber (2013) argue that once people think about a political object, that object has an "affective tag" (a positive or negative feeling) stored in memory, which then influences subsequent information-processing and leads to "motivated reasoning." Both accounts suggest that persuasion is possible, but when people have relevant prior attitudes, and especially strongly held attitudes, they are less likely to change their attitudes in response to new information.

This pattern suggests more potential for persuasion in down-ballot races, where people have thought less about the candidates and have fewer stored considerations and weaker affective tags, if any. As Delli Carpini and Keeter (1996) show, Americans are more familiar with national political figures, such as the president and vice-president, than with figures like US Senators. Indeed, the percentage of Americans 
who could name both Senators declined between 1947 and 1989, even as the percentage who could name the vice-president increased. Likewise, Hopkins (2018) shows that the percentage of Americans who can name their governor declined from $87 \%$ in 1947 to $66 \%$ in 2007. Hopkins also finds that Americans could supply less information about governors than presidents when asked to describe them, and they were less likely to search the Internet for information about governors than presidents. These declines are likely linked to the decreasing amount of news coverage of state and local politics (Hayes and Lawless Forthcoming). Research on congressional elections also finds differences in knowledge across levels of office. In particular, a larger percentage of Americans can recall and recognize the names of US Senate candidates than US House candidates (Jacobson and Carson 2019). Here again, knowledge of congressional candidates is linked to how much local news covers congressional campaigns (Hayes and Lawless 2018).

These informational and attitudinal asymmetries across levels of political office imply that new information-such as in television advertising-should more strongly influence views of down-ballot candidates than views of presidential candidates. ${ }^{2}$ The persuasive potential of campaigns and campaign advertising is evident in previous research. Campaigns provide information to voters, who become better able to name candidates (Elms and Sniderman 2006; Jacobson 2006) and identify where the candidates stand on political issues (Alvarez 1998; Franklin 1991; Johnston, Hagen, and Jamieson 2004; Patterson and McClure 1972). Television advertising specifically contributes both to informational gains (Freedman, Franz, and Goldstein 2004) and changes in attitudes toward the candidates (Coppock, Hill, and Vavreck 2020; Freedman and Goldstein 1999; Huber and Arceneaux 2007; Johnston, Hagen, and Jamieson 2004; Ridout and Franz 2011). ${ }^{3}$ Moreover, Huber and Arceneaux (2007) show that changes in attitudes toward the candidates - that is, persuasion-are an important mechanism by which television advertisements influence vote intentions. This potential for persuasion is in line with the strategies of candidates themselves, who air advertising primarily on programs with audiences containing many swing voters (Lovett and Peress 2010).

Synthesizing this prior work on information, persuasion, and advertising leads to several expectations. We expect that television advertising has a larger effect on election outcomes in down-ballot races for Congress, governor, and other statewide offices than in presidential races. In terms of pathways for this effect, we expect that voters are less likely to have opinions about downballot candidates and, when they do have opinions, these opinions are weaker than their opinions about

\footnotetext{
${ }^{2}$ Even in presidential races, advertising may have a larger effect on views of the lesser-known candidate (Broockman and Kalla 2020). ${ }^{3}$ Beyond the direct effects of ads, they may also help inform voters by spurring people to seek information via other sources (Canen and Martin 2020).
}

presidential candidates. Therefore, we expect that television advertising has a larger effect on voters' knowledge and attitudes about down-ballot candidates compared with presidential candidates. Evidence for these latter two expectations will suggest that persuasion is a primary mechanism by which advertising affects election outcomes.

A contrasting expectation is that television advertising affects outcomes mainly through its effect on whether partisans turn out to vote. Although political advertising does not appear to have a significant effect on overall turnout (Ashworth and Clinton 2007; Krasno and Green 2008; Lovett and Peress 2010; Spenkuch and Toniatti 2018; but see Green and Vavreck 2008), it could affect the partisan composition of the electorate if candidates' ads mobilize their own partisans and demobilize their opponent's partisans in roughly equal amounts. Prior research has found that the partisan composition of the electorate is associated with partisan campaign activity aggregated across levels of office (McGhee and Sides 2005) as well as national party spending (Holbrook and McClurg 2011). Most relevant to this study is Spenkuch and Toniatti (2018), who find that presidential television advertising is associated with the partisan composition of the electorate in the 2004-12 elections.

If advertising matters mainly through partisan mobilization, then, contrary to the first expectation, advertising should have a similar relationship to election outcomes across levels of office. Assuming that partisans vote for their party's candidate at similar rates across levels of office, any shifts in partisan turnout induced by advertising should affect candidates up and down the ballot in roughly equal amounts. We test for partisan mobilization in two ways: by examining the relationship between advertising and partisan turnout across several election cycles and by examining the relationship between advertising at one level of office and outcomes at other levels. Any "spillover" across levels of office suggests that ads affect partisan turnout and thus affect races other than the one the ads are targeting.

\section{DATA AND RESEARCH DESIGN}

To evaluate the effect of political advertising, we built a panel dataset of election returns and advertising data at the county level that substantially extends similar datasets in other work (e.g., Fowler, Ridout, and Franz 2016; Ridout and Franz 2011; Shaw 2006; Sides, Tesler, and Vavreck 2018; Sides and Vavreck 2013). This dataset's considerable temporal and geographic scope, alongside a credible research design, provides a rigorous test of the causal effect of advertising on thousands of election outcomes.

We assembled 2000-2018 national, state, and local election returns from various sources. For presidential, senate, and gubernatorial elections, we used data from CQ's Voting and Elections Collection. For House elections during this period, we used data from the Atlas of U.S. Elections (Leip 2016), which break the 


\section{FIGURE 1. Democratic Advertising Advantage (in 100s of ads) across Geography in an Illustrative Set of Offices and Years}

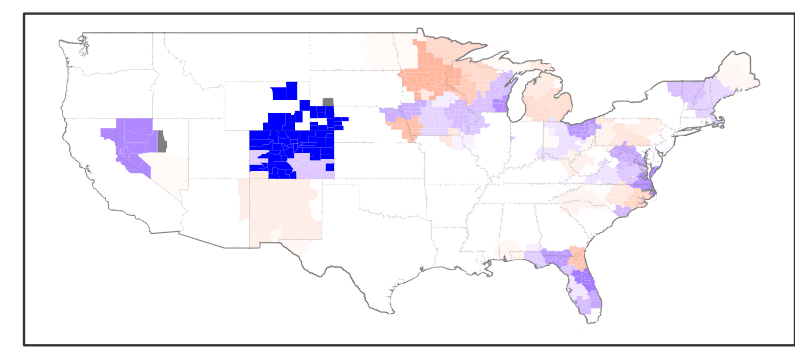

Dem. Ad. Advantage $-20$ 0

(a) Presidential Race, 2012

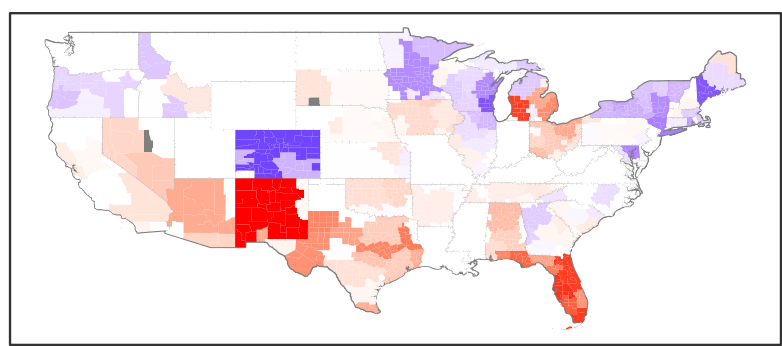

Dem. Ad. Advantage $-40$ $-20$ 20

(c) Governor Races, 2014

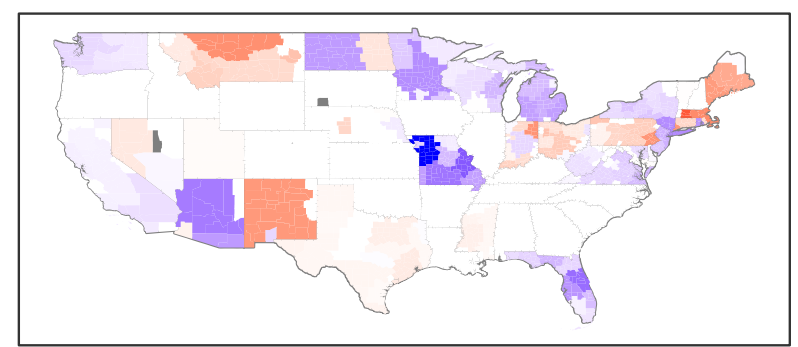

Dem. Ad. Advantage $\quad-20 \quad 0 \quad 20 \quad 40$

(b) Senate Races, 2012

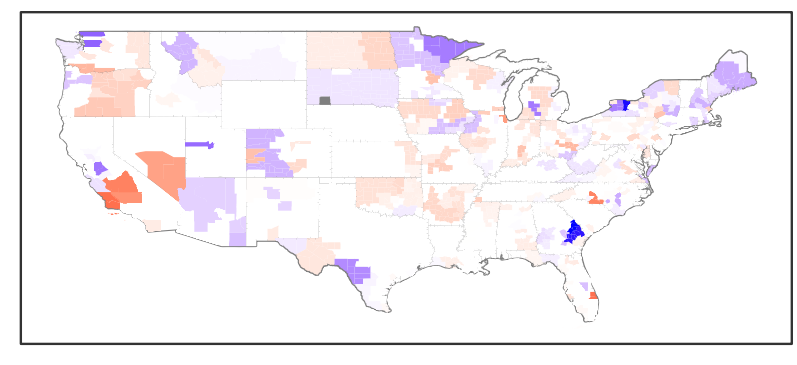

Dem. Ad. Advantage $\quad-10 \quad 0 \quad 10 \quad 20$

(d) House Races, 2012

Note: Positive (bluer) values show a pro-Democratic advantage and negative (redder) values show a pro-Republican advantage.

congressional election returns down by county. ${ }^{4}$ For other state offices (i.e., attorney general and treasurer), we used crowd-sourced county-level data from OurCampaigns.com. ${ }^{5}$

Our primary treatment variable is the net Democratic advantage in the number of broadcast television ad airings in a county over the last two months (64 days) of the campaign. Similar measures have been used in prior research on advertising effects (e.g., Franz and Ridout 2007; Lovett and Peress 2010; Spenkuch and Toniatti 2018). To be sure, this measure does not capture all advertising, an increasing percentage of which is aired on local cable outlets or online. But broadcast television advertisements constituted the vast majority of campaign advertising during this period (Fowler, Ridout, and Franz 2016).

We calculate the net Democratic advertising advantage by taking the difference between the number of Democratic and Republican ad airings for a particular race in each media market using advertising data obtained under license from the Wesleyan Media

\footnotetext{
${ }^{4}$ Both the CQ and Atlas of U.S. Elections data were obtained under a restricted license.

${ }^{5}$ Thirty-six states elect state treasurers and 43 elect attorneys general.
}

Project and the Wisconsin Advertising Project (Fowler, Franz, and Ridout 2020). ${ }^{6}$ These data include the top 75 media markets in the 2000 election cycle, the top 100 markets in the 2002, 2004, and 2006 cycles, and all 210 media markets since 2008. ${ }^{7}$ Figure 1 displays the net Democratic ad advantage in each media market for an illustrative set of offices and years. It shows not only the comprehensiveness of our data but how much advertising volume varies across offices and geography.

We include all general election advertising supporting the Democratic and Republican candidates in each race, including ads aired by the candidate's campaign, parties, and outside groups. ${ }^{8}$ Our focus on advertising in the last two months of the campaign reflects the

\footnotetext{
${ }^{6}$ The Wisconsin Ads Project data can be obtained at https://elections. wisc.edu/wisconsin-advertising-project/, and the Wesleyan Media Project can be obtained at https://mediaproject.wesleyan.edu/dataac cess/.

${ }^{7}$ We assign counties to media markets based on the Nielsen definitions of media markets. We use data on these assignments from Sood (2016) and manually checked how these assignments vary over time based on individual Broadcasting and Cable Yearbooks.

${ }^{8}$ The Wesleyan Media Project and Wisconsin Advertising Project data include a variable that identifies primary and general elections ads in 2000 and 2012-2020. We used this variable to drop primary election ads from our analysis in those years. In other years (20022010) we dropped all ads that were aired before the primary election date in each state.
} 
extant finding that ads aired closer to Election Day are more effective than ads aired earlier in the election cycle (e.g., Sides, Tesler, and Vavreck 2018; Sides and Vavreck 2013). ${ }^{9}$

One limitation of this measure is that it does not account for the size of the television audience that could have seen each ad airing. However, counts of ad airings are highly correlated with measures, such as gross ratings points, that do attempt to account for the number of people possibly exposed. ${ }^{10}$

We use two parallel research designs to estimate the causal effect of television advertising on election outcomes. The first design includes all US counties in the media markets contained in the advertising data (e.g., all counties starting in 2008 and a subset of counties before that). We include either county fixed effects to account for time-invariant confounders in each county or a lagged outcome variable in lieu of county fixed effects. ${ }^{11}$ These account for the overall partisan orientation of each county. We also include state-year fixed effects to control for time-varying confounders at the state and national levels (Fowler and Hall 2018; de Benedictis-Kessner and Warshaw 2020). The stateyear fixed effects account for trends in the political preferences of each state across election years, such as the pro-Republican trend in Ohio or the pro-Democratic trend in Arizona. They also account for racespecific dynamics in each state, such as the strength of the candidates and any incumbency advantage. In our analysis of congressional districts, we use district-year fixed effects to account for the strength of the candidates in each race. Thus, this research design isolates the effects of advertising from other aspects of candidates' quality and spending. ${ }^{12}$

\footnotetext{
${ }^{9}$ In Appendix G, we provide more evidence, showing that ads aired in the summer have no effect on election outcomes, but ads aired in both September and in October affect outcomes and to roughly the same extent.

${ }^{10}$ In 2006, we have measures of both ad airings and gross ratings points (GRP's) for 69 candidates in nine media markets across five states (MI, MN, OH, IL, IN). These candidates were running for US House of Representatives (60), Senate (4), and Governor (5). Across the 42 days leading up to election day, the correlation at the candidate-market-day level between ad airings and GRP's ranges from 0.89 to 1.0 for candidates who ran 10 or more ads. The average correlation across all candidate-market-days is 0.97 . In 2012, the correlation between ads aired and GRP's for presidential candidates Barack Obama and Mitt Romney was similarly high. In the 159 days leading up to the 2012 general election, the correlation between airings and GRP's at the candidate-market-day level was 0.99 for both Obama and Romney. We estimate that each ad airing was worth 3-4 GRP's in the 2012 presidential race.

${ }^{11} \mathrm{We}$ do not include county fixed effects in the model with the lagged outcome variable to avoid issues of Nickell bias that can arise in datasets with a small number of periods (Beck and Katz 2011; Nickell 1981).

${ }^{12}$ We cluster our standard errors at the county level to account for serial correlation in errors. We also cluster by media market-year to account for the fact that each county in a market receives the same dosage of advertising during a particular election year (Abadie et al. 2017). In Appendix A, we show how the standard errors for our point estimates of advertising effects in presidential races vary using different clustering strategies. In general, different clustering strategies
}

Although this panel design addresses a host of possible confounders, it may miss the effect of unobserved time-varying confounders at the media market or county levels that could bias our estimates. In particular, campaigns could be strategically targeting their spending in areas of a state where they expect to do well by using information, such as internal polls, that is unavailable to researchers.

Our second research design accounts for this possibility by restricting the sample to counties in the same state that are adjacent to one another but on different sides of the border of a media market. Spenkuch and Toniatti (2018) use this design to study the effects of television advertising in the 2004-2012 presidential elections. Similarly, Huber and Arceneaux (2007) use media market boundaries to study the effects of television advertising in the 2000 presidential election. Other studies have used discontinuities in treatment exposure across county or state boundaries to study the incumbency advantage (Ansolabehere, Snowberg, and Snyder 2006) and the effects of policies like Medicaid expansion and right-to-work laws (e.g., Clinton and Sances 2018; Feigenbaum, Hertel-Fernandez, and Williamson 2018).

The intuition behind the border county design is that within a state, adjacent counties that straddle the border of a media market are likely to be similar to one another except that they are on different sides of the media market boundary and therefore may be exposed to different levels of television advertising. Moreover, this variation in advertising spending is plausibly exogenous to characteristics of these border counties. It seems unlikely that advertising is targeted based on the characteristics of specific border counties, especially because the counties on media market boundaries exclude the urban cores of most media markets. For evidence that border county designs achieve balance on many characteristics of counties that could also affect election outcomes, see Spenkuch and Toniatti (2018).

To illustrate this design, Figure 2 shows the border counties in Pennsylvania (shaded in gray). It confirms that most major cities (e.g., Philadelphia, Pittsburgh, Erie, and Scranton) are not in border counties. The adjacent counties that do lie along media market borders tend to be similar to one another. For example, Indiana and Cambria counties are adjacent to each other along the boundary between the Pittsburgh and Johnstown-Altoona media markets. Both counties are largely rural areas where Mitt Romney received about $58 \%$ of the vote in the 2012 presidential election.

To execute the border county design, we match each county in a state with every other adjacent county that lies on the other side of a media market boundary. The unit of analysis becomes the border county pair, with the two counties on opposite sides of a media market boundary. Thus, a particular county could be in this

produce similar standard errors and much smaller standard errors than if we did not cluster at all. 


\section{FIGURE 2. Illustration of the Border Counties Design in Pennsylvania}

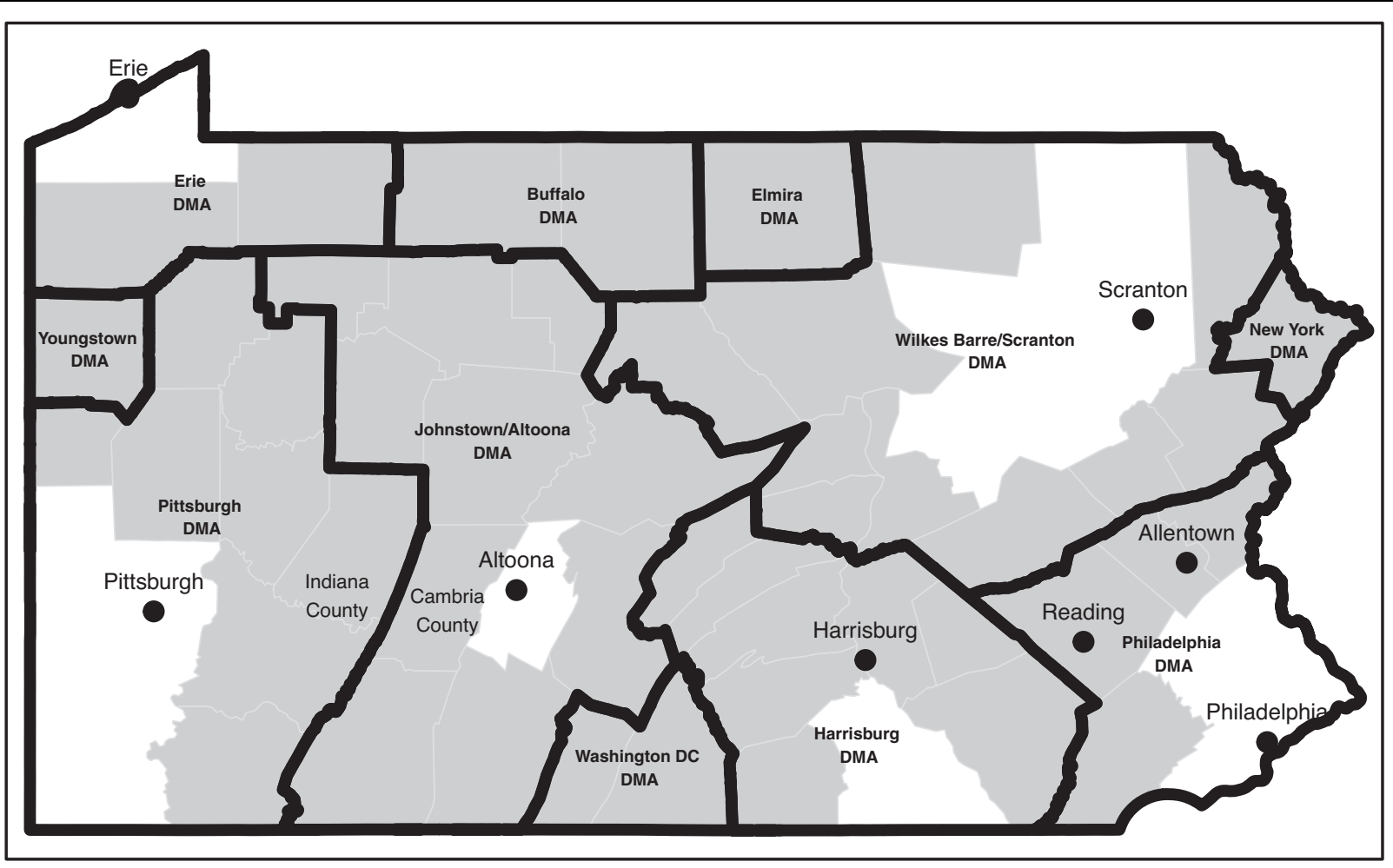

Note: The dark lines indicate media market boundaries. The shaded counties, which lie along a media market boundary next to another county in Pennsylvania, are the ones included in the border county sample.

sample multiple times if it borders multiple counties in this fashion. For this reason, the overall sample size is larger in this design than in the first design. ${ }^{13}$ In analyzing this sample of border counties, we include county fixed effects to account for time-invariant confounders in each county. Crucially, we also include year-specific fixed effects for each pair of border counties. This accounts for the effect of any year-specific unobserved confounders in each border-pair of counties, such as trends in their partisanship or ideology. Thus, only confounders that vary between border counties within a particular election cycle could bias our results using this design. While it is impossible to rule out these confounders, there appears to be no correlation between changes in political advertising and border counties' time-varying observable characteristics (Spenkuch and Toniatti 2018).

To test the assumption that there are no time-varying confounders, typically called the parallel trends assumption, we examined whether future values of television advertising appear to have a significant effect on current outcomes. For both designs, we find that future advertising has no effect on election results (see Appendix B). The fact that both research designs

\footnotetext{
${ }^{13}$ We cluster standard errors in the border county sample by county and media market border-year to ensure that this process does not artificially increase our statistical precision (Abadie et al. 2017).
}

generally pass this "placebo test" suggests that timevarying confounders are not biasing our results. Overall, we believe that the "border county design" is more rigorous than the "all counties" design. But it relies on a much smaller set of counties and could have less external validity. As a result, we use both designs throughout the analysis.

Table 1 shows summary statistics of advertising across offices in all counties and in border county pairs (in hundreds of ads) across 2000-2018. Our treatment variable - the Democratic advertising advantage in the last two months before the election-captures the balance of ads favoring each of the opposing major-party candidates. On average, there is considerable balance such that the mean Democratic advantage is close to 0 in most levels of office other than presidential elections. In presidential elections, Democrats have a modest advantage on average, driven in particular by their advantages in the 2004, 2008, and 2016 elections. But there is considerable variation both across counties and within counties and border county pairs. ${ }^{14}$ This variation is particularly large in races for president,

\footnotetext{
${ }^{14}$ The standard deviations within counties or border pairs are based on the residuals in ad advantage from the fixed effect regression models in Table 3. For more on using this kind of standard deviation, see Mummolo and Peterson (2018).
} 
TABLE 1. Summary Data on Broadcast Television Advertising 2000-2018

\begin{tabular}{|c|c|c|c|c|c|c|c|c|}
\hline \multicolumn{9}{|c|}{ All counties } \\
\hline & \multicolumn{2}{|c|}{ Levels of ads } & \multicolumn{6}{|c|}{ Dem. ad advantage } \\
\hline & Dem. ads & Rep. ads & Dem. ad adv. & SD & SD & & & \\
\hline & Mean & Mean & Mean & across county & within county & Min & Max & Sample \\
\hline President & 15.79 & 11.71 & 4.08 & 11.80 & 6.09 & -26.89 & 105.17 & 12,652 \\
\hline Senate & 17.58 & 16.37 & 1.21 & 12.07 & 5.41 & -49.53 & 145.00 & 17,133 \\
\hline Governor & 17.79 & 17.88 & -0.08 & 12.13 & 5.07 & -88.27 & 42.56 & 11,373 \\
\hline House & 4.49 & 3.75 & 0.75 & 5.56 & 2.08 & -34.71 & 74.47 & 28,642 \\
\hline Attorney gen. & 3.05 & 2.96 & 0.11 & 4.09 & 1.84 & -18.56 & 15.24 & 7,984 \\
\hline Treasurer & 0.88 & 0.79 & 0.11 & 2.05 & 0.89 & -10.00 & 7.48 & 5,331 \\
\hline \multicolumn{9}{|c|}{ Border counties } \\
\hline & \multicolumn{2}{|c|}{ Levels of ads } & \multicolumn{6}{|c|}{ Dem. ad advantage } \\
\hline & Dem. ads & Rep. ads & Dem. ad adv. & SD & SD & & & \\
\hline & Mean & Mean & Mean & $\overline{\text { across county }}$ & $\overline{\text { within county }}$ & Min & Max & Sample \\
\hline President & 15.96 & 11.82 & 4.15 & 11.97 & 4.68 & -26.89 & 105.17 & 17,689 \\
\hline Senate & 15.41 & 14.45 & 0.96 & 11.08 & 4.34 & -49.53 & 145.00 & 23,910 \\
\hline Governor & 15.92 & 16.74 & -0.82 & 11.53 & 4.09 & -88.27 & 42.56 & 15,880 \\
\hline House & 3.75 & 3.16 & 0.58 & 5.07 & 1.75 & -34.71 & 74.47 & 38,138 \\
\hline Attorney gen. & 2.64 & 2.71 & -0.08 & 3.70 & 1.40 & -18.56 & 15.24 & 11,557 \\
\hline Treasurer & 0.86 & 0.76 & 0.12 & 2.03 & 0.70 & -10.00 & 7.48 & 7,520 \\
\hline
\end{tabular}

Senate, and Governor, where there is more advertising overall.

\section{ADVERTISING EFFECTS IN PRESIDENTIAL ELECTIONS}

We begin by examining the effects of advertising on the Democratic candidate's major-party vote share in presidential elections between 2000 and 2016. The first four columns of Table 2 show the results of regression models using all counties where we have advertising data. The first column shows a naive model with just fixed effects for year. This model suggests that a 100airing advantage yields an additional 0.158 percentage points of vote share. The next column shows the results of a model with year and county fixed effects. The county fixed effects, which address time-invariant confounders, dramatically decrease the estimated effect to 0.043 points, or about four hundredths of a percentage point. The third column shows the results of a model that includes state-year fixed effects and a lagged outcome variable. In this model, a 100-airing advantage for the Democratic candidate is associated with a 0.037 point increase in vote share over the candidate's vote share in the previous election. The fourth column includes state-year fixed effects, which address timevarying confounders at the state-level as well as county fixed effects. Here, the same advantage is associated with a 0.027 -point increase in vote share.

The next three columns show the estimated effects of presidential ad airings among pairs of counties along media market borders. In the model that includes stateyear fixed effects and a lagged outcome variable, a 100airing advantage for the Democratic candidate is associated with a 0.027 -point increase in vote share (column 5 ). Including state-year fixed effects and county fixed effects produces an estimate of 0.020 points (column 6). Including border-pair-year fixed effects and county fixed effects produces an estimate of 0.018 points (column 7). ${ }^{15}$

\footnotetext{
${ }^{15}$ The results in column 7 closely resemble the results in Spenkuch and Toniatti (2018), who use a similar design. They find that a onestandard-deviation shift in advertising is associated with a shift in vote margin of about 0.5 percentage points, which is equivalent to a change in two-party vote share of 0.25 percentage points. Our results imply that a one-standard-deviation (across counties) change in advertising advantage leads to a change in two-party vote share of 0.22 percentage points. The similarity of the two results is notable because Spenkuch and Toniatti (2018) employ a more refined measure of advertising that uses auxiliary data on television audiences to estimate the number of times the average person in each county saw ads for each candidate. Thus, the difference between this measure and our simpler measure of advertising advantage does not seem to affect the results.
} 


\section{TABLE 2. The Effects of Television Advertising in Last Two Months of Presidential Elections} (2000-2016)

Dependent variable: Dem. vote share

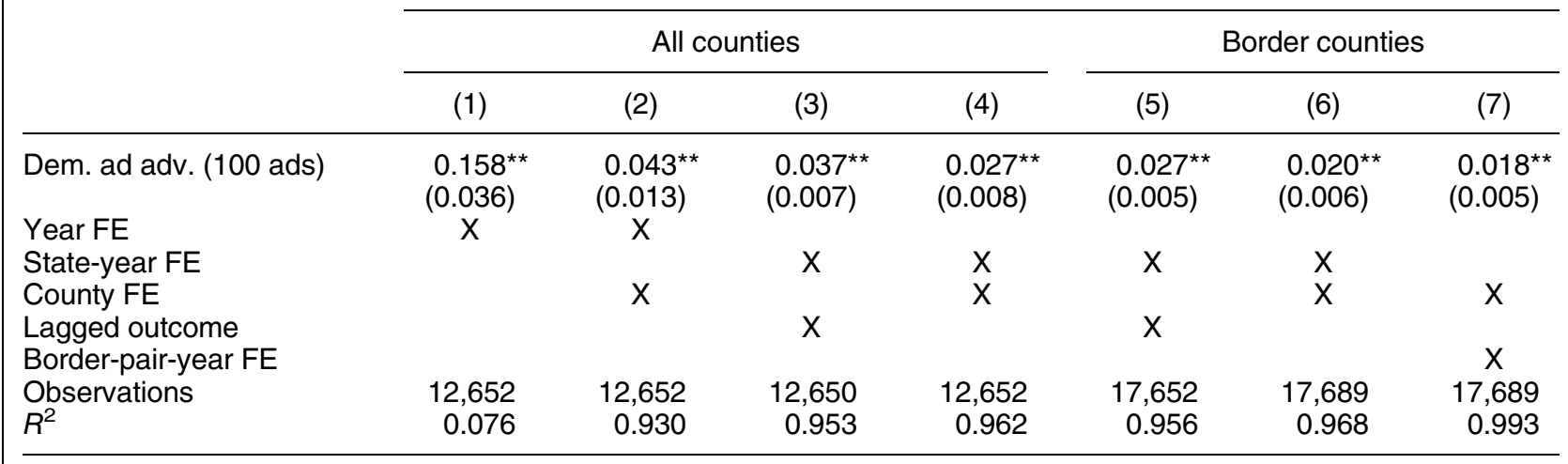

Note: The treatment variable is Democratic ad advantage in terms of hundreds of ads. Standard errors are clustered by county and DMAyear in the left panel and by county and DMA border-year in the right panel. ${ }^{*} p<0.05 ;{ }^{* *} p<0.01$.

These results show that a more stringent modeling strategy produces a smaller effect of televised advertising on presidential election outcomes. This illustrates the importance of either employing fixed effects or isolating border counties (or both) to avoid overstating the effect. It also bolsters a causal interpretation of our results that we recover similar estimates with two different identification strategies. Ultimately, televised advertising in presidential elections appears to have a modest but detectable relationship to vote share, as previous literature has found. ${ }^{16}$

Our results also place a rough upper bound on the real-world effects of advertising in presidential general elections. Assuming that the effects of ads are linear, our findings imply that moving from three standard deviations below the average advertising advantage to three standard deviations above the average (a 6-standard-deviation shift) within border pairs would lead to a 0.5 -point change in two-party vote share.

\section{ADVERTISING EFFECTS IN DOWN-BALLOT ELECTIONS}

How does the effect of televised advertising in presidential elections compare with its effects in other types of elections? The top panel of Table 3 shows the effect of advertising across different offices using the all county sample. Here, we use the specification with both

\footnotetext{
${ }^{16}$ We find similar results in models in which we first-difference the treatment and outcome variables to calculate changes from the previous election cycle and in models that include a linear time trend for each county. We also investigated whether advertising effects are changing over time (see Appendix I). We find no evidence of any decrease in advertising effects in more recent election cycles. Finally, for presidential elections from 2004 to 2016, we examined whether accounting for the presence of Democratic candidate field offices affects our results (see Appendix C). We found no evidence for this, suggesting that the estimated effects of ads are not confounded by the campaign activity associated with field offices, such as canvassing.
}

county and state-year fixed effects (column 4 of Table 2). The bottom panel of Table 3 shows the effect of advertising across different offices using the border county sample and the specification with county and adjacent-county-year fixed effects (column 7 of Table 2). ${ }^{17}$

The results from both designs tell the same story: a similar-sized ad-airing advantage has much larger effect in down-ballot elections than in presidential elections. Column 1 recapitulates the earlier finding that a 100-airing advantage in presidential elections leads to about a 0.02-point increase in two-party vote share. But this advantage leads to a 0.04-0.06-point increase in vote share in Senate elections (column 2), a 0.06-0.09-point increase in gubernatorial elections (column 3), a 0.08-0.09-point increase in House elections (column 4), a 0.19-0.26-point increase in Attorney General elections (column 5), and a 0.34-0.35-point increase in state Treasurer elections (column 6). The effect of a particular ad advantage can be anywhere between 2.5 and 19 times greater in down-ballot races than in presidential races. ${ }^{18}$

Figure 3 shows the results graphically based on the border counties design in Table $3 .{ }^{19}$ Specifically, it shows the effect of variation in each party's advertising between -3 and +3 within-unit standard deviations of the mean within border pairs. We noted earlier that this effect of advertising was about 0.5 percentage points in presidential races. It is larger down-ballot: about 1 point in Senate races, 1.35 points in governor races, 0.9 points

\footnotetext{
${ }^{17}$ In Appendix D, we show the results using all the models we reported for presidential races in Table 2.

${ }^{18}$ We find substantively similar results using regression models that are weighted by county population.

${ }^{19}$ For this figure, we first calculate the residuals based on the fixed effects models in Table 3. This approach is similar to Figure 1 in Gerber et al. (2011). We then plot the relationship between the residualized treatment and outcome variables. We show the binned residuals to make the graphs simpler, but the fit lines on each graph are based on all of the data.
} 
TABLE 3. Effects of Aggregate Television Advertising in Last Two Months of Election across Offices (2000-2018)

\begin{tabular}{|c|c|c|c|c|c|c|}
\hline & \multicolumn{6}{|c|}{ Dependent variable: Dem. vote share } \\
\hline & President & Senate & Governor & House & Attorney gen. & Treasurer \\
\hline & $(1)$ & $(2)$ & (3) & (4) & (5) & (6) \\
\hline \multicolumn{7}{|c|}{ All counties } \\
\hline $\begin{array}{l}\text { Dem. ad adv. (100 ads) } \\
\text { County FE } \\
\text { State-year FE } \\
\text { Observations } \\
R^{2}\end{array}$ & $\begin{array}{c}0.027^{\star \star} \\
(0.008) \\
X \\
X \\
12,652 \\
0.962\end{array}$ & $\begin{array}{c}0.055^{\star \star} \\
(0.010) \\
X \\
X \\
17,133 \\
0.960\end{array}$ & $\begin{array}{c}0.087^{\star \star} \\
(0.014) \\
X \\
X \\
11,373 \\
0.941\end{array}$ & $\begin{array}{c}0.091^{\star *} \\
(0.018) \\
X \\
X \\
28,641 \\
0.953\end{array}$ & $\begin{array}{c}0.260^{\star *} \\
(0.046) \\
X \\
X \\
7,984 \\
0.967\end{array}$ & $\begin{array}{c}0.337^{\star \star} \\
(0.087) \\
X \\
X \\
5,331 \\
0.971\end{array}$ \\
\hline \multicolumn{7}{|c|}{ Border counties } \\
\hline $\begin{array}{l}\text { Dem. ad adv. (100 ads) } \\
\text { County FE } \\
\text { Border-pair-year FE } \\
\text { Observations } \\
R^{2}\end{array}$ & $\begin{array}{c}0.018^{\star *} \\
(0.005) \\
X \\
X \\
17,689 \\
0.993\end{array}$ & $\begin{array}{c}0.038^{\star *} \\
(0.007) \\
X \\
X \\
23,910 \\
0.990\end{array}$ & $\begin{array}{c}0.055^{\star \star} \\
(0.010) \\
X \\
X \\
15,880 \\
0.986\end{array}$ & $\begin{array}{c}0.084^{\star *} \\
(0.022) \\
X \\
X \\
38,131 \\
0.991\end{array}$ & $\begin{array}{c}0.192^{\star \star} \\
(0.031) \\
X \\
X \\
11,557 \\
0.991\end{array}$ & $\begin{array}{l}0.352^{\star \star} \\
(0.056) \\
X \\
X \\
7,520 \\
0.993\end{array}$ \\
\hline
\end{tabular}

in House races, 1.6 points in Attorney General races, and 1.5 points in Treasurer races. ${ }^{20}$

Not only does advertising have a larger effect in down-ballot races, but it does so at a lower cost. ${ }^{21}$ For presidential races, we estimate that the cost per vote is about $\$ 365$, or somewhat more than the $\$ 170$ per vote estimated by Spenkuch and Toniatti (2018) based on the cost of advertising in the 2008 presidential election. A $\$ 10$ million advantage in an individual state might gain a candidate 27,000 votes, or enough to tip Nevada, Maine, Michigan, Wisconsin, and New Hampshire in the 2016 election. The cost per vote is much lower in other offices: about $\$ 200$ in Senate races and $\$ 125$ in gubernatorial races. This suggests that a very plausible ad advantage of $\$ 2$ million in a Senate race would gain a candidate about 10,000 votes, which is also enough to tip several races in recent years. In addition, the cost per vote from advertising, especially in down-ballot races, is comparable to that of other campaign activities (Green and Gerber 2019, Table 12-1). This may explain why campaigns continue to spend so much on television advertising.

\footnotetext{
${ }^{20}$ The differences across levels of office in the shifts associated with a 6-standard-deviation change appear smaller than the differences in the regression coefficients themselves. This is because there are fewer ads in down-ballot races, and thus the variation in either party's advantage is more limited. As a result, a standard-deviation shift in a state treasurer race entails a smaller change in the raw balance of advertising compared to a higher level of office like the presidency. ${ }^{21}$ These calculations are based on the estimated average cost per ad in the Wesleyan Median Project data in 2016, the average population of DMAs where ads were aired, and the point estimates from the border counties model in Table 3 .
}

To be sure, these calculations of advertising effects and the implied cost per vote assume that the marginal returns to advertising are constant - that is, they do not diminish as the number of ads aired in a race increases. Figure 3 suggests that advertising advantage does have a fairly linear relationship with vote share. In Appendix E, we examine this question in more detail and find little apparent evidence of diminishing returns. Only at very high levels of advertising do there appear to be diminishing returns. But even at these high levels, vote share is almost always increasing at the margins, suggesting that candidates are still getting something for their dollar. Moreover, these high levels of advertising rarely translate into an advertising advantage for either candidate because the two sides typically match each other's advertising. Thus, there is little reason for candidates to cease advertising, especially if their opponent continues to stay on the air. ${ }^{22}$

\section{MECHANISMS: PERSUASION AND PARTISAN MOBILIZATION}

What mechanism best accounts for the fact that the effect of television advertising on election outcomes differs across levels of office? We first provide evidence for the mechanism of persuasion - that is, advertising provides information that helps persuade existing voters to support a particular candidate.

Testing for this mechanism requires measures of voters' knowledge and perceptions of candidates at

\footnotetext{
$\overline{22}$ Spenkuch and Toniatti (2018, Appendix C) also show that advertising in presidential races has approximately linear effects.
} 


\section{FIGURE 3. Effect of Democratic Advertising Advantage on Democratic Vote Share}

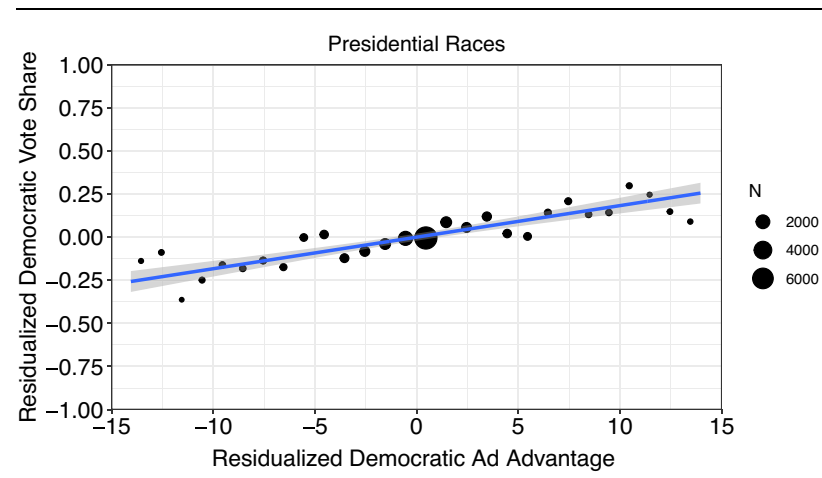

(in hundreds of ads)

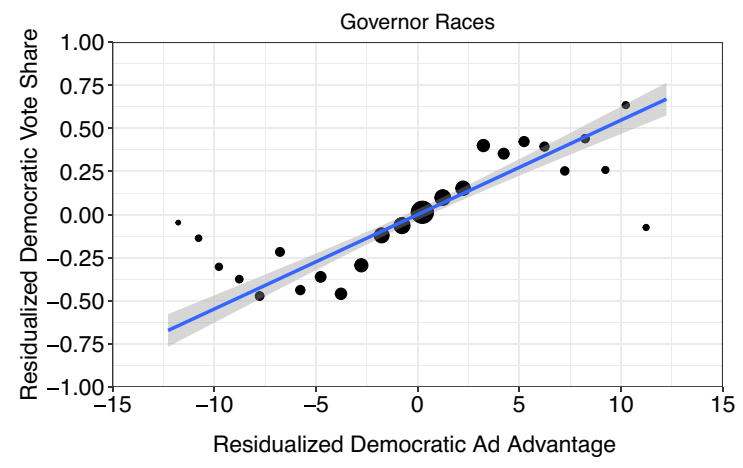

(in hundreds of ads)

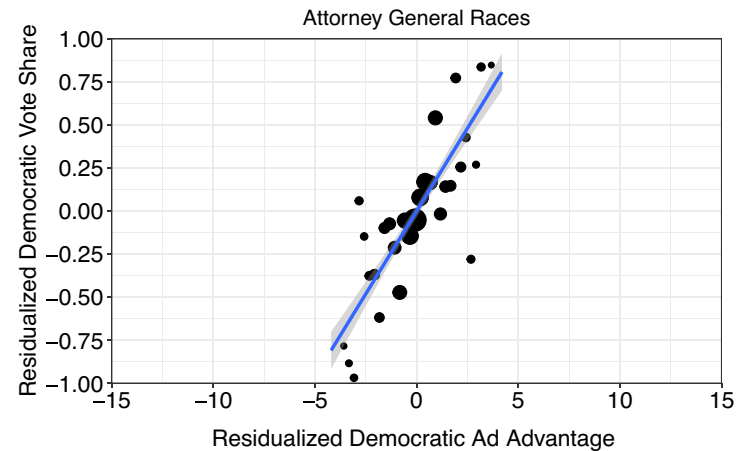

(in hundreds of ads)

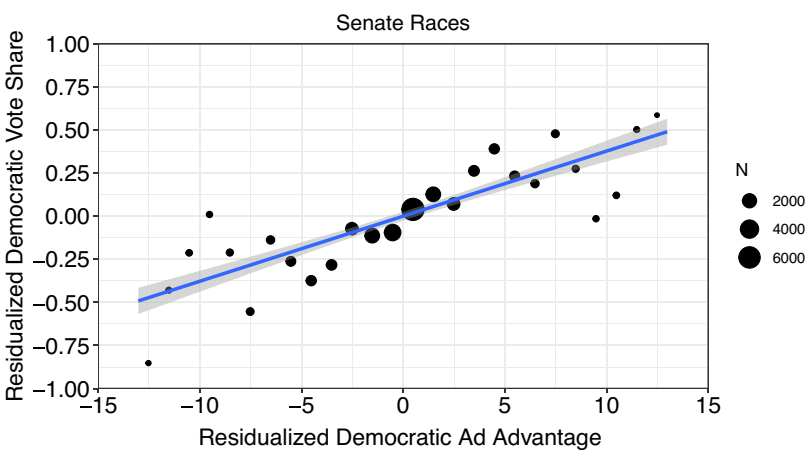

(in hundreds of ads)

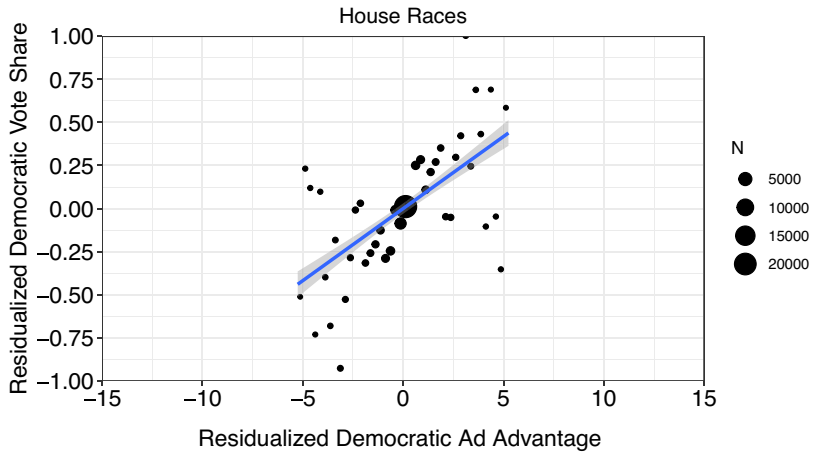

(in hundreds of ads)

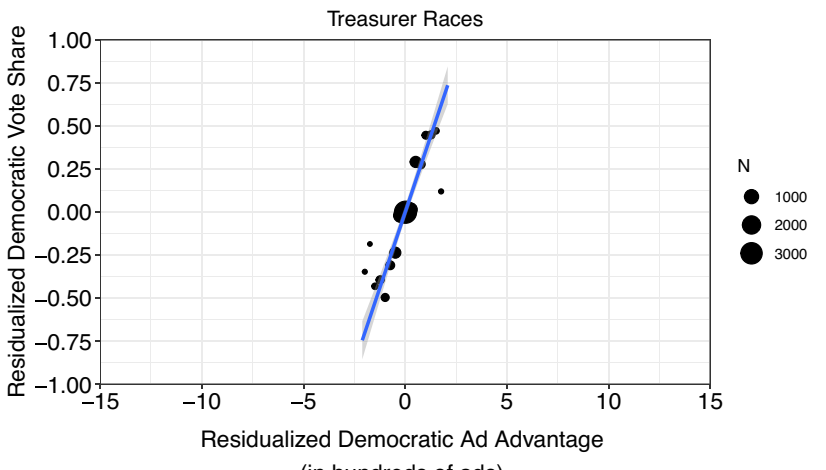

(in hundreds of ads)

Note: These graphs show the implied effects of a \pm 3 -standard-deviation shift in Democratic ad advantage for each office. They are based on the residuals from the border counties models in Table 3. The $x$-axes are the same across plots to enhance comparability. The sizes of the dots reflect the number of paired county-year observations in the respective $x$-axis bin.

multiple levels of office. Although only a few surveys include such measures - and, any relationship between individual-level voter attitudes and advertising is necessarily correlational-the evidence suggests that television advertising provides voters information and shapes their views of candidates. Moreover, these effects are larger in down-ballot races than in presidential races.

\section{Lower Levels of Opinion Formation and Strength in Down-Ballot Races}

One expectation is that voters should be less likely to have opinions about down-ballot candidates and, if they do, less likely to have strong opinions. This creates riper conditions for persuasion.

We test this expectation in three sets of surveys that contain identical measures of attitudes toward candidates at various levels of office. Two surveys, the 2000 National Annenberg Election Study (NAES) and the American National Election Study (ANES), include measures of favorability toward presidential, US Senate, and US House candidates using a feeling thermometer. We measure whether voters have an opinion based on whether they were able to rate candidates. We also measure the strength of opinions based on whether respondents gave strongly favorable or unfavorable opinions (0-10 or $90-100$ on the feeling thermometer). 
A third survey, the Cooperative Congressional Election Study (CCES), asks respondents to place presidential, Senate, and House candidates on a seven-point ideological scale ranging from very liberal to very conservative. Again, because respondents could express no opinion, we can measure their level of information about or familiarity with the candidates. We also capture a rough proxy for the strength of their opinion - here, whether they placed a candidate at one of the endpoints of the scale ( 1 or 7$)$.

To illustrate the general pattern, we average the results in two ways. First, we average the ANES and CCES surveys across years, although the same patterns do hold within the individual survey years. ${ }^{23}$ Second, we average views of the opposing candidates to create one quantity for each level of office, acknowledging that there can be variation within levels of office depending on the visibility of the individual candidates.

Table 4 presents the percentage of respondents who could not rate or place the candidate and the percentage of respondents who had an "extreme" rating or placement (among those who had an opinion). The findings confirm expectations. First, a much larger percentage of respondents fail to rate House and Senate candidates or place them on this ideological scale, compared with presidential candidates. For example, almost all respondents could rate the presidential candidates on feeling thermometers, but between $20 \%$ and $40 \%$ could not rate House or Senate candidates. Senate candidates were marginally more familiar than House candidates. It was also much harder for respondents to place House or Senate candidates on ideological scales. Indeed, an average of nearly half $(47 \%)$ of CCES respondents could not place House candidates.

Second, among those who could rate or place the candidates, a larger percentage had extreme views of presidential candidates than Senate or House candidates. In the ANES data, for example, an average of $21 \%$ of respondents rated the presidential candidates very unfavorably or very favorably, but $10 \%$ or less did this for Senate or House candidates. In the CCES, a smaller fraction placed Senate or House candidates at the endpoints of the ideological scale as well.

To be sure, these results are hardly definitive. Because the surveys are conducted during or after the election campaign in each year, they cannot capture attitudes before exposure to campaign advertising. However, this likely militates against finding information asymmetries across levels of office, especially given the stronger relationship between advertising and voter attitudes about down-ballot candidates, which we report below. Thus, these results still suggest that the persuasive potential of advertising should be larger in down-ballot races.

\footnotetext{
${ }^{23}$ For the ANES, we focus on years where we have advertising data and comparable measures of attitudes across levels of office (2000, 2004, 2008, 2012, and 2016). We rely only on the ANES face-to-face interviews to help ensure comparability over time.
}

\section{Larger Effects of Advertising on Views of Down-Ballot Candidates}

If advertising helps persuade voters, the other main empirical implication is that it will have larger effects on knowledge about and feelings toward candidates in down-ballot races relative to presidential races. We evaluate this claim in two ways.

First, we evaluate whether advertising helps inform voters about the candidates. For each respondent in the 2006-18 CCES surveys, we calculate the percentage of candidates for each office for whom they provide an ideological placement. We then regress this percentage on the total number of ads at each level of office aired in the month prior to the survey interview. These models also include constituency-year-period fixed effects and control for pretreatment demographic characteristics of respondents (gender, race, education, and age).

We find that ads reduce the percentage of "don't know" responses at each level of office but do so much more in down-ballot races (Table 5). For every additional 100 ads aired, there is a very modest (and statistically insignificant) decline in the proportion of presidential candidates that the respondents cannot place on this ideological scale. But the same number of ads creates a decline that is about seven times larger in Senate races and 16 times larger in House races. In the ANES data, advertising also reduces the proportion of respondents who cannot rate the candidates on a feeling thermometer and, again, especially in downballot races. Advertising appears to increase knowledge to a greater extent in exactly those races where knowledge is less prevalent.

Second, we evaluate whether advertising appears to have a larger effect on voters' attitudes about downballot candidates compared with its influence on attitudes about presidential candidates. We operationalize attitudes in terms of both candidates' valence (likeability, quality, experience, etc.) and their ideological proximity to voters. We examine these two characteristics because they derive from prominent theories of how voters make decisions (e.g., Buttice and Stone 2012). (To be sure, we are not testing these theories or making claims about their explanatory power.)

We assess valence in the NAES and ANES surveys by subtracting the Republican candidate's favorability score from the Democrat's score to produce the Democrat's valence advantage. We then regress this valence advantage on the Democratic ad advantage in a model that also includes state and year fixed effects and pretreatment demographic characteristics (gender, race, education, and age). ${ }^{24}$

The top panel of Table 6 shows the results from the ANES. A 100-ad advantage has no effect on the Democrats' valence advantage in the 2000-16 presidential elections but increased valence advantages by much

\footnotetext{
${ }^{24}$ The public-use ANES files do not include county codes. So we merged respondents with our advertising data based on their congressional districts. The measurement error in this matching process likely slightly attenuates our results using the ANES.
} 
TABLE 4. The Existence and Extremity of Views about Presidential, Senate, and US House Candidates

\begin{tabular}{lccc|}
\hline & President & Senate & House \\
\hline Percentage cannot rate on feeling thermometer & & & \\
2000 National Annenberg Election Study & 4 & 28 & 39 \\
2000-2016 American National Election Study & 1 & 20 & 31 \\
Percentage cannot place on ideological scale & & 37 & 47 \\
2006-2018 Cooperative Congressional Election Study & 15 & 28 & 27 \\
Percentage with extreme rating (among those with who rated) & 34 & 10 & 8 \\
2000-2016 American National Election Study & 21 & 27 & 22 \\
Percentage with extreme placement (among those who placed) & 35 & & \\
2006-2018 Cooperative Congressional Election Study & & & \\
\hline
\end{tabular}

TABLE 5. The Effects of Advertising on Knowledge of the Candidates

\begin{tabular}{|c|c|c|c|}
\hline & President & Senate & House \\
\hline & $(1)$ & $(2)$ & (3) \\
\hline \multicolumn{4}{|c|}{ Dependent variable: Don’t know ideology } \\
\hline Total ads per race (100 ads) & $\begin{array}{c}-0.011 \\
(0.012)\end{array}$ & $\begin{array}{c}-0.118^{\star \star \star} \\
(0.017)\end{array}$ & $\begin{array}{c}-0.261^{\star * *} \\
(0.039)\end{array}$ \\
\hline $\begin{array}{l}\text { Years } \\
\text { Constituency-year FE } \\
\text { Individual-level controls }\end{array}$ & $\begin{array}{c}2006-2018 \\
x \\
x\end{array}$ & $\begin{array}{c}2006-2018 \\
x \\
X\end{array}$ & $\begin{array}{c}2006-2018 \\
x \\
x\end{array}$ \\
\hline $\begin{array}{l}\text { Observations } \\
R^{2} \\
\text { Source: CCES Surveys }\end{array}$ & $\begin{array}{c}144,236 \\
0.084\end{array}$ & $\begin{array}{c}248,708 \\
0.273\end{array}$ & $\begin{array}{c}309,798 \\
0.264\end{array}$ \\
\hline \multicolumn{4}{|c|}{ Dependent variable: Don't know on feeling thermometer } \\
\hline Total ads per race (100 ads) & $\begin{array}{c}-0.005^{\star} \\
(0.003)\end{array}$ & $\begin{array}{c}-0.084^{\star \star} \\
(0.018)\end{array}$ & $\begin{array}{c}-0.443^{\star *} \\
(0.054)\end{array}$ \\
\hline $\begin{array}{l}\text { Years } \\
\text { State FE } \\
\text { Year FE } \\
\text { Individual-level controls }\end{array}$ & $\begin{array}{c}2000-2016 \\
x \\
x \\
x\end{array}$ & $\begin{array}{c}2000-2016 \\
x \\
x \\
x\end{array}$ & $\begin{array}{c}2000-2016 \\
x \\
X \\
X\end{array}$ \\
\hline $\begin{array}{l}\text { Observations } \\
R^{2} \\
\text { Source: ANES Surveys }\end{array}$ & $\begin{array}{l}8,190 \\
0.029\end{array}$ & $\begin{array}{l}4,870 \\
0.145\end{array}$ & $\begin{array}{l}6,863 \\
0.145\end{array}$ \\
\hline
\end{tabular}

more in Senate elections (0.23) and House elections $(0.52)$. In the NAES, the effect of ads on candidates' favorability ratings is also larger for down-ballot candidates than for presidential candidates, although the point estimates have larger standard errors due to smaller sample sizes.

Next, we examine whether advertising affects the ideological proximity between voters and candidates. Using the 2006-2018 CCES surveys, we calculate proximity as the absolute distance between the self-placement of respondents and their placement of candidates on the seven-point ideology scale. We then calculate the ideological advantage of the Democratic candidate as respondents' ideological congruence with Democratic candidates minus their congruence with Republican candidates. We regress this proximity advantage on the Democratic ad advantage, constituency-year and county fixed effects, and demographic characteristics of respondents (gender, race, education, and age).

The bottom panel of Table 6 shows the results. A 100-ad Democratic advantage in presidential elections is associated with a 0.007 increase in the Democratic candidate's proximity advantage $(p=0.07)$. This same ad advantage is associated with a 0.012 shift in Senate elections and a 0.010 shift in House elections $(p=0.20)$. Although these results are not as clear-cut as the 
TABLE 6. The Effects of Advertising on Candidate Valence and Ideological Proximity

\begin{tabular}{|c|c|c|c|}
\hline & President & Senate & House \\
\hline & (1) & (2) & (3) \\
\hline \multicolumn{4}{|c|}{ Dependent variable: Democratic feeling therm. advantage } \\
\hline Dem. ad adv. (100 ads) & $\begin{array}{c}0.011 \\
(0.079)\end{array}$ & $\begin{array}{l}0.234^{*} \\
(0.090)\end{array}$ & $\begin{array}{l}0.523^{*} \\
(0.196)\end{array}$ \\
\hline $\begin{array}{l}\text { Year } \\
\text { State FE } \\
\text { Year FE } \\
\text { Individual-level controls }\end{array}$ & $\begin{array}{c}2000-16 \\
X \\
X \\
X\end{array}$ & $\begin{array}{c}2000-16 \\
x \\
X \\
x\end{array}$ & $\begin{array}{c}2000-16 \\
x \\
x \\
x\end{array}$ \\
\hline $\begin{array}{l}\text { Observations } \\
R^{2}\end{array}$ & $\begin{array}{l}8,145 \\
0.160\end{array}$ & $\begin{array}{l}3,259 \\
0.122\end{array}$ & $\begin{array}{l}2,899 \\
0.113\end{array}$ \\
\hline \multicolumn{4}{|c|}{ Source: ANES cumulative file (face-to-face/phone samples) } \\
\hline \multicolumn{4}{|c|}{ Dependent variable: Democratic favorability advantage } \\
\hline Dem. ad adv. (100 ads) & $\begin{array}{c}0.238 \\
(0.146)\end{array}$ & $\begin{array}{l}0.839^{\star \star} \\
(0.254)\end{array}$ & $\begin{array}{c}1.205 \\
(0.861)\end{array}$ \\
\hline $\begin{array}{l}\text { Year } \\
\text { State FE } \\
\text { Individual-level controls }\end{array}$ & $\begin{array}{l}2000 \\
X \\
X\end{array}$ & $\begin{array}{c}2000 \\
X \\
X\end{array}$ & $\begin{array}{l}2000 \\
x \\
x\end{array}$ \\
\hline $\begin{array}{l}\text { Observations } \\
R^{2} \\
\text { Source: NAES }\end{array}$ & $\begin{array}{c}24,077 \\
0.079\end{array}$ & $\begin{array}{l}4,653 \\
0.093\end{array}$ & $\begin{array}{l}1,093 \\
0.111\end{array}$ \\
\hline \multicolumn{4}{|c|}{ Dependent variable: Democratic ideological advantage } \\
\hline Dem. ad adv. (100 ads) & $\begin{array}{c}0.007 \\
(0.004)\end{array}$ & $\begin{array}{l}0.012^{\star *} \\
(0.004)\end{array}$ & $\begin{array}{c}0.010 \\
(0.007)\end{array}$ \\
\hline $\begin{array}{l}\text { Years } \\
\text { Constituency-year FE } \\
\text { Individual-level controls }\end{array}$ & $\begin{array}{c}2006-2018 \\
x \\
x\end{array}$ & $\begin{array}{c}2006-2018 \\
x \\
x\end{array}$ & $\begin{array}{c}2006-2018 \\
X \\
X\end{array}$ \\
\hline $\begin{array}{l}\text { Observations } \\
R^{2} \\
\text { Source: CCES Surveys }\end{array}$ & $\begin{array}{c}116,353 \\
0.118\end{array}$ & $\begin{array}{c}134,177 \\
0.061\end{array}$ & $\begin{array}{c}109,551 \\
0.084\end{array}$ \\
\hline
\end{tabular}

valence results, they also suggest that television advertising can influence perceived spatial proximity to the candidates, and more so in down-ballot races than presidential races.

\section{Partisan Turnout as an Alternative Mechanism}

Finally, we examine whether television advertising influences election outcomes by altering the balance of Democrats and Republicans who vote. This mechanism is not consistent with the results thus far, especially the differing effects of ads across levels of office, but it deserves a formal test nonetheless. To conduct a test, we obtained administrative data from state voter files compiled by the firm Catalist. These data contain the percentage of Democrats and Republicans that voted in each county in the elections between 2008 and 2018. This includes the 31 states that record party registration and 18 states where Catalist models partisanship based on demographics and local voting patterns. ${ }^{25}$ We calculate the Democratic Party's turnout advantage as the difference between the percentage of Democrats that turn out to vote and the percentage of Republicans that turn out. We then model this as a function of the Democratic Party's overall advertising advantage, summing all advertising across presidential, Senate, governor, House, Attorney General, and Treasurer races. This does not capture every advertisement, as there are a small number of ads

\footnotetext{
${ }^{25}$ The modeled partisanship scores are based on a model that gives each voter a single partisanship score from 2008 to 2020. The results are similar if we focus only on states that record party registration. For a similar approach, see Hall and Thompson (2018), who examine whether partisan turnout is the mechanism that explains the poor performance of ideological extremists in House elections. Finally, note that we were unable to obtain administrative data on turnout in California.
} 


\section{TABLE 7. The Effects of Advertising on Partisan Turnout}

\begin{tabular}{lcc}
\hline & \multicolumn{2}{c}{ Dependent variable: } \\
\cline { 2 - 3 } & \multicolumn{2}{c}{ Dem. turnout adv. } \\
\cline { 2 - 3 } & All counties & $\begin{array}{c}\text { Border } \\
\text { counties }\end{array}$ \\
\cline { 2 - 3 } & $(1)$ & $(2)$ \\
\hline Dem. ad adv. (100 ads) & $0.015^{\star *}$ & $\begin{array}{c}0.002 \\
(0.003)\end{array}$ \\
\hline Observations & 18,338 & $(0.002)$ \\
$R^{2}$ & 0.880 & $\begin{array}{c}25,976 \\
0.942\end{array}$ \\
\hline
\end{tabular}

Note: Standard errors clustered by county and DMA-year in top panel and county and DMA border-year in bottom panel. ${ }^{*} p<$ $0.05 ;{ }^{* *} p<0.01$.

for other offices, ballot propositions, and so on, but it does capture the vast majority of ads that could affect partisan turnout. To estimate these models, we use the entire set of counties from these states as well as the relevant border county pairs, just as in our analyses of advertising and election outcomes.

Overall, the results are mixed (Table 7). In the model with all counties, a Democratic ad advantage is associated with a small turnout advantage for Democrats (and vice versa for Republicans), but in the model with border county pairs, there is no relationship. This latter null result is arguably more credible because this model is less vulnerable to time-varying confounders or trends than is the all-counties model. For instance, if one party's candidates all tend to target more ads to a county that is trending in their direction, this could lead to a spurious finding of advertising effects. But even in the all-counties model, the size of the point estimate $(b$ $=0.015)$ is small enough that partisan turnout cannot explain advertising's effect on election outcomes, particularly in down-ballot elections. This is because a small effect of advertising on partisan turnout, combined with the modest relationship of partisan turnout to election outcomes, implies a small total effect on election outcomes (see Appendix F for more details). ${ }^{26}$

A second test of whether advertising affects partisan turnout is whether advertising aired to influence one level of office "spills over" and affects outcomes at other levels. ${ }^{27}$ For example, if a Democratic advantage in presidential election advertising increases the

\footnotetext{
${ }^{26}$ In Appendix F, we also show that controlling for the relative turnout of Democrats and Republicans barely changes the relationship between advertising and election outcomes, again suggesting that partisan turnout is unlikely to be the main mechanism underlying advertising effects.

${ }^{27}$ Spillover has not been explored in the literature on political advertising, but studies of commercial advertising find evidence of spillover-in particular from the advertiser to competitors who sell similar products (e.g., Sahni 2016; Shapiro 2018), which mirrors what we would expect if advertising from a political candidate helped other candidates in the same party.
}

Democratic advantage in turnout overall, this should help Democratic candidates down the ballot. We estimate the same county-level models of election outcomes including not only advertising in that race but also advertising in other races. If advertising spills over across races, we would expect that advertising in other offices would affect vote margins.

We do not find consistent spillover at any level of office (Table 8). In the model using all counties, there is evidence of small spillover effect, but the border counties model shows no such effects. This is consistent with the evidence in Table $7 .{ }^{28}$ Taken together, advertising's effect on election outcomes - and especially its differential effect across levels of office - has more to do with persuasion than the mobilization of partisans.

\section{CONCLUSION}

Television advertising is the cornerstone of many campaigns for political office in the United States. As scholars have developed more detailed data and sophisticated estimation strategies, they have shown that television advertising is related to election outcomes: the larger a candidate's advantage in advertising compared with that of their opponent, the larger their share of the vote. The extant literature has demonstrated this in some presidential and US Senate elections. But no study has systematically examined the effect of advertising across levels of office, including different types of down-ballot races.

We have provided the most comprehensive analysis of advertising effects to date. We find that television advertising affects election results across all levels of office but that the effects of advertising are substantially larger in down-ballot elections than presidential elections. Despite increasing partisanship in the electorate, there are still persuadable voters that respond to television advertising - especially in down-ballot elections, where voters have less information about candidates. Of course, this relative difference in advertising's effect does not mean that its effect is "large" in some absolute sense or large enough to potentially change the outcome of an election. That would be most likely in close races where one party is able to muster a substantial advertising advantage. But we do not claim that this is a common occurrence.

We also provide important evidence for the mechanism that underlies this relationship between advertising and election outcomes. We show that advertising has larger effects in down-ballot races because it provides new information and changes voters' attitudes about the candidates. We show that voters clearly have less information and weaker opinions about candidates in down-ballot races. We also show that advertising has

\footnotetext{
${ }^{28}$ In Appendix H, we also show that there are no clear differences between ad effects in presidential and midterm election years, as might be expected if differential turnout was driving our results and especially if presidential advertising affected turnout in down-ballot races.
} 
TABLE 8. Spillover of Television Advertising across Offices (2000-2018)

\begin{tabular}{|c|c|c|c|c|c|}
\hline & \multicolumn{5}{|c|}{ Dependent variable: Dem. vote share } \\
\hline & President & Senate & Governor & Att. gen. & Treasurer \\
\hline & (1) & (2) & (3) & (4) & (5) \\
\hline \multicolumn{6}{|c|}{ All counties } \\
\hline Dem. ad adv. (100 ads) & $\begin{array}{l}0.024^{\star \star} \\
(0.008)\end{array}$ & $\begin{array}{l}0.052^{* *} \\
(0.010)\end{array}$ & $\begin{array}{l}0.075^{\star \star} \\
(0.013)\end{array}$ & $\begin{array}{l}0.200^{\star *} \\
(0.041)\end{array}$ & $\begin{array}{l}0.334^{\star \star} \\
(0.082)\end{array}$ \\
\hline Dem. ad adv. in other races & $\begin{array}{l}0.016^{\star} \\
(0.007)\end{array}$ & $\begin{array}{l}0.017^{* *} \\
(0.006)\end{array}$ & $\begin{array}{l}0.030^{\star *} \\
(0.007)\end{array}$ & $\begin{array}{l}0.033^{\star \star} \\
(0.007)\end{array}$ & $\begin{array}{l}0.029^{\star *} \\
(0.007)\end{array}$ \\
\hline County FE & $\mathrm{X}$ & $\mathrm{X}$ & $\mathrm{X}$ & $\mathrm{X}$ & $\mathrm{X}$ \\
\hline State-year FE & $\mathrm{X}$ & $\mathrm{x}$ & $\mathrm{x}$ & $\mathrm{x}$ & $\mathrm{x}$ \\
\hline Observations & 12,652 & 17,133 & 11,373 & 7,984 & 5,331 \\
\hline$R^{2}$ & 0.962 & 0.960 & 0.941 & 0.967 & 0.971 \\
\hline \multicolumn{6}{|c|}{ Border counties } \\
\hline Dem. ad adv. (100 ads) & $\begin{array}{l}0.018^{\star \star} \\
(0.005)\end{array}$ & $\begin{array}{l}0.038^{* *} \\
(0.007)\end{array}$ & $\begin{array}{l}0.054^{* *} \\
(0.010)\end{array}$ & $\begin{array}{l}0.187^{\star *} \\
(0.031)\end{array}$ & $\begin{array}{l}0.348^{\star \star} \\
(0.057)\end{array}$ \\
\hline Dem. ad adv. in other races & $\begin{array}{c}-0.0002 \\
(0.004)\end{array}$ & $\begin{array}{l}-0.001 \\
(0.005)\end{array}$ & $\begin{array}{c}0.003 \\
(0.005)\end{array}$ & $\begin{array}{c}0.004 \\
(0.005)\end{array}$ & $\begin{array}{c}0.006 \\
(0.005)\end{array}$ \\
\hline County FE & $\mathrm{x}$ & $\mathrm{X}$ & $\mathrm{X}$ & $\mathrm{X}$ & $\mathrm{X}$ \\
\hline Border-pair-year FE & $\mathrm{X}$ & $\mathrm{X}$ & $\mathrm{X}$ & $\mathrm{X}$ & $\mathrm{X}$ \\
\hline Observations & 17,689 & 23,910 & 15,880 & 11,557 & 7,520 \\
\hline$R^{2}$ & 0.993 & 0.990 & 0.986 & 0.991 & 0.993 \\
\hline
\end{tabular}

a stronger relationship with the formation and direction of attitudes about the candidates. In short, advertising appears to persuade voters. We find less evidence for a competing mechanism - that advertising mobilizes partisans to vote.

This evidence about mechanisms is important in at least two ways. For one, it helps clarify how a central form of campaign communication influences voters. Campaigns obviously care about both persuasion and mobilization, albeit to varying degrees. But different campaign tactics can be more or less effective at these different tasks. Our evidence suggests that the primary benefit of television advertising is providing voters with information and shifting their attitudes about the candidate.

Second, evidence about individual-level mechanisms addresses the forces that create over-time changes in aggregate election outcomes. As Hill, Hopkins, and Huber $(2021,1)$ note, "Changes in partisan outcomes between consecutive elections must come from changes in the composition of the electorate or changes in the vote choices of consistent voters." Both of these pathways are important, but in recent elections, including 2012 and 2016, persuasion has been particularly important (Hill, Hopkins, and Huber 2021). Television advertising is thus potentially crucial to explaining both the choices of individual voters and why outcomes shift from election to election.

We are also mindful of the limitations of our analysis. Our findings do not necessarily address the effects of advertising in other media, such as online media. Some evidence suggests that advertising online reflects different strategic goals than persuasion, such as fundraising (Ridout, Fowler, and Franz 2021, 8). It is also the case that current political trends - such as the rise of online electioneering and the decline of split-ticket voting (Jacobson 2021) - could eventually lead to a decrease in the effect of television advertising on elections. However, we do not yet see evidence that its effect has changed over the 18 -year period that we study (see Appendix I).

Our findings also do not address the effects of the specific messages in ads, such as which issues they focus on or whether they primarily support or attack a candidate. Our data and research design are well suited to identifying the effects of advertising volume but not these other characteristics. ${ }^{29}$ Future studies can build on our research to specify what components of ads most help to persuade voters (see, e.g., Gordon et al. 2019).

\section{SUPPLEMENTARY MATERIALS}

To view supplementary material for this article, please visit http://doi.org/10.1017/S000305542100112X.

\footnotetext{
${ }^{29}$ On the challenges of generating causal estimates of advertising tone, see Blackwell (2013).
} 


\section{DATA AVAILABILITY STATEMENT}

Research documentation and most of the data that support the findings of this study are openly available at the American Political Science Review Dataverse: https://doi.org/10.7910/DVN/F8JXHR. As we discussed in the main text in footnotes 4 and 6 , some of the elections and advertising data for our analyses are obtained under restricted license. We provide more details in the readme file on the Dataverse about how researchers can obtain and compile these files.

\section{ACKNOWLEDGMENTS}

We wish to thank the editors and anonymous reviewers for their feedback. We are grateful for feedback from Justin de Benedictis-Kessner, David Broockman, Kevin Collins, Rich Davis, James Mulhall, Robert Erikson, Anthony Fowler, Don Green, Andrew Hall, Ethan Porter, Julian Wamble, Michael Miller, Eitan Hersh, Seth Hill, Dan Hopkins, Josh Kalla, Otis Reid, Aaron Strauss, Travis Ridout, and Daron Shaw. We also appreciate feedback from participants in workshops at George Washington University, Vanderbilt University, Stony Brook University, and the University of Maryland.

\section{CONFLICT OF INTEREST}

The authors declare no ethical issues or conflicts of interest in this research.

\section{ETHICAL STANDARDS}

The authors affirm this research did not involve human subjects.

\section{REFERENCES}

Abadie, Alberto, Susan Athey, Guido W Imbens, and Jeffrey Wooldridge. 2017. "When Should You Adjust Standard Errors for Clustering?" NBER Working Paper. https://www.nber.org/papers/ w24003.

Alvarez, R. Michael. 1998. Information and Elections. Ann Arbor: University of Michigan Press.

Angrist, Joshua David, and Jörn-Steffen Pischke. 2009. Mostly Harmless Econometrics: An Empiricist's Companion. Princeton, NJ: Princeton University Press.

Ansolabehere, Stephen, and Alan Gerber. 1994. "The Mismeasure of Campaign Spending: Evidence from the 1990 U.S. House Elections." Journal of Politics 4 (56): 1106-18.

Ansolabehere, Stephen, Erik C. Snowberg, and James M. Snyder. 2006. "Television and the Incumbency Advantage in US Elections.” Legislative Studies Quarterly 31 (4): 469-90.

Ashworth, Scott, and Joshua D. Clinton. 2007. "Does Advertising Exposure Affect Turnout?" Quarterly Journal of Political Science 2 (1): 27-41.

Beck, Nathaniel, and Jonathan N. Katz. 2011. "Modeling Dynamics in Time-Series-Cross-Section Political Economy Data." Annual Review of Political Science 14: 331-52.
Benoit, William L. 2018. Televised Political Advertisements. https:// www.oxfordbibliographies.com/view/document/obo9780199756841/obo-9780199756841-0124.xml.

Blackwell, Matthew. 2013. "A Framework for Dynamic Causal Inference in Political Science." American Journal of Political Science 57 (2): 504-20.

Broockman, David E., and Joshua L. Kalla. 2020. "When and Why Are Campaigns Persuasive Effects Small? Evidence from the 2020 US Presidential Election.” Working Paper. https://osf.io/m7326/.

Buttice, Matthew K., and Walter J. Stone. 2012. "Candidates Matter: Policy and Quality Differences in Congressional Elections." Journal of Politics 74 (3): 870-87.

Canen, Nathan, and Gregory Martin. 2020. "How Campaign Ads Stimulate Political Interest." SSRN Working Paper.

Clinton, Joshua D., and Michael W. Sances. 2018. "The Politics of Policy: The Initial Mass Political Effects of Medicaid Expansion in the States." American Political Science Review 112 (1): 167-85.

Coppock, Alexander, Seth J. Hill, and Lynn Vavreck. 2020. "The Small Effects of Political Advertising Are Small Regardless of Context, Message, Sender, or Receiver: Evidence from 59 RealTime Randomized Experiments." Science Advances 6 (36): eabc4046.

de Benedictis-Kessner, Justin, and Christopher Warshaw. 2020. "Accountability for the Local Economy at All Levels of Government in United States Elections." American Political Science Review 114 (3): 660-76.

DellaVigna, Stefano, and Matthew Gentzkow. 2010. "Persuasion: Empirical Evidence." Annual Review of Economics 2: 643-69.

Delli Carpini, Michael X., and Scott Keeter. 1996. What Americans Know about Politics and Why It Matters. New Haven, CT: Yale University Press.

Elms, Laurel, and Paul M. Sniderman. 2006. "Informational Rhythms of Incumbent-Dominated Congressional Campaigns." In Capturing Campaign Effects, eds. Henry E. Brady and Richard Johnston, 221-41. Ann Arbor: University of Michigan Press.

Erikson, Robert S., and Kent L. Tedin. 2019. American Public Opinion: Its Origins, Content, and Impact. New York: Routledge.

Feigenbaum, James, Alexander Hertel-Fernandez, and Vanessa Williamson. 2018. "From the Bargaining Table to the Ballot Box: Political Effects of Right to Work Laws." NBER Working Paper. https://www.nber.org/papers/w24259.

Fowler, Anthony, and Andrew B. Hall. 2018. "Do Shark Attacks Influence Presidential Elections? Reassessing a Prominent Finding on Voter Competence." Journal of Politics 80 (4): 1423-37.

Fowler, Erika Franklin, Michael Franz, and Travis Rideout. 2016. Political Advertising in the United States. Boulder, CO: Westview Press.

Fowler, Erika Franklin, Michael M. Franz, and Travis N. Ridout. 2020. Political Advertising Dataset [computer file]. The Wesleyan Media Project, Department of Government at Wesleyan University [distributor]. http://mediaproject.wesleyan.edu.

Fowler, Erika Franklin, Travis N. Ridout, and Michael M. Franz. 2016. "Political Advertising in 2016: The Presidential Election as Outlier?" The Forum 14 (4): 445-69.

Franklin, Charles H. 1991. "Eschewing Obfuscation? Campaigns and the Perception of U.S. Senate Incumbents." American Political Science Review 85 (4): 1193-214.

Franz, Michael M., and Travis N. Ridout. 2007. "Does Political Advertising Persuade?" Political Behavior 29 (4): 465-91.

Freedman, Paul, Michael Franz, and Kenneth Goldstein. 2004. "Campaign Advertising and Democratic Citizenship." American Journal of Political Science 48 (4): 723-41.

Freedman, Paul, and Ken Goldstein. 1999. "Measuring Media Exposure and the Effects of Negative Campaign Ads." American Journal of Political Science 43 (4): 1189-208.

Gerber, Alan S., James G. Gimpel, Donald P. Green, and Daron R. Shaw. 2011. "How Large and Long-Lasting Are the Persuasive Effects of Televised Campaign Ads? Results from a Randomized Field Experiment.” American Political Science Review 105 (1): 733-51.

Goldstein, Ken, and Paul Freedman. 2000. "New Evidence for New Arguments: Money and Advertising in the 1996 Senate Elections." Journal of Politics 62 (4): 1087-108. 
Goldstein, Kenneth, and Travis N. Ridout. 2004. "Measuring the Effects of Televised Political Advertising in the United States." Annual Review of Political Science 7: 205-26.

Gordon, Brett R., and Wesley R. Hartmann. 2013. "Advertising Effects in Presidential Elections." Marketing Science 32 (1): 19-35.

Gordon, Brett R., Mitchell J. Lovett, Bowen Luo, and James Reeder III. 2019. "Disentangling the Effects of Ad Tone on Voter Turnout and Candidate Choice in Presidential Elections." SSRN Working Paper.

Green, Donald P., and Alan S. Gerber. 2019. Get Out the Vote: How to Increase Voter Turnout. Washington, DC: Brookings Institution Press.

Green, Donald P., and Jonathan Krasno. 1988. "Salvation for the Spendthrift Incumbent: Reestimating the Effects of Campaign Spending in House Elections." American Journal of Political Science 32 (4): 884-907.

Green, Donald P., and Lynn Vavreck. 2008. "Analysis of ClusterRandomized Experiments: A Comparison of Alternative Estimation Approaches." Political Analysis 16 (2): 138-52.

Hall, Andrew B., and Daniel M. Thompson. 2018. "Who Punishes Extremist Nominees? Candidate Ideology and Turning out the Base in US Elections." American Political Science Review 112 (3): 509-24.

Hayes, Danny, and Jennifer L. Lawless. 2018. "The Decline of Local News and Its Effects: New Evidence from Longitudinal Data." Journal of Politics 80 (1): 332-36.

Hayes, Danny, and Jennifer L. Lawless. Forthcoming. News Hole: The Demise of Local Journalism and Political Engagement. New York: Cambridge University Press.

Hill, Seth J., Daniel J. Hopkins, and Gregory A. Huber. 2021. "Not by Turnout Alone: Measuring the Sources of Electoral Change, 2012 to 2016." Science Advances 7 (17): eabe3272.

Hill, Seth J., James Lo, Lynn Vavreck, and John Zaller. 2013. "How Quickly We Forget: The Duration of Persuasion Effects from Mass Communication." Political Communication 30 (4): 521-47.

Holbrook, Thomas M., and Scott D. McClurg. 2011. "The Mobilization of Core Supporters: Campaigns, Turnout, and Electoral Composition in United States Presidential Elections." American Journal of Political Science 49: 689-703.

Hopkins, Daniel J. 2018. The Increasingly United States: How and Why American Political Behavior Nationalized. Chicago: University of Chicago Press.

Huber, Gregory A., and Kevin Arceneaux. 2007. "Identifying the Persuasive Effects of Presidential Advertising." American Journal of Political Science 51 (4): 957-77.

Jacobson, Gary C. 1975. "The Impact of Broadcast Campaigning on Electoral Outcomes." Journal of Politics 37 (3): 769-93.

Jacobson, Gary C. 1978. "The Effects of Campaign Spending in Congressional Elections." American Political Science Review 72 (2): 469-91.

Jacobson, Gary C. 2006. "Measuring Campaign Spending Effects in U.S. House Elections." In Capturing Campaign Effects, eds. Henry E. Brady and Richard Johnston, 199-220. Ann Arbor: University of Michigan Press.

Jacobson, Gary C. 2015. "How Do Campaigns Matter?” Annual Review of Political Science 18: 31-47.

Jacobson, Gary C. 2021. "Driven to Extremes: Donald Trump's Extraordinary Impact on the 2020 Elections." Presidential Studies Quarterly 51(3): 492-521.

Jacobson, Gary C., and Jamie L. Carson. 2019. The Politics of Congressional Elections. Lanham, MD: Rowman \& Littlefield.

Johnston, Richard, Michael G. Hagen, and Kathleen Hall Jamieson. 2004. The 2000 Presidential Election and the Foundations of Party Politics. Cambridge: Cambridge University Press.

Kahn, Kim Fridkin, and Patrick J. Kenney. 1999. "Do Negative Campaigns Mobilize or Suppress Turnout? Clarifying the Relationship between Negativity and Participation." American Political Science Review 93 (4): 877-89.

Kalla, Joshua L., and David E. Broockman. 2018. "The Minimal Persuasive Effects of Campaign Contact in General Elections: Evidence from 49 Field Experiments." American Political Science Review 112 (1): 148-66.
Krasno, Jonathan S., and Donald P. Green. 2008. "Do Televised Presidential Ads Increase Voter Turnout? Evidence from a Natural Experiment." Journal of Politics 70 (1): 245-61.

Lau, Richard R., and Gerald M. Pomper. 2004. Negative Campaigning: An Analysis of U.S. Senate Elections. Lanham, MD: Rowman \& Littlefield.

Leip, Dave. 2016. U.S. House General County Election Results [computer file]. Version V2. Harvard Dataverse [distributor] https://doi.org/10.7910/DVN/T2DQQS.

Lodge, Milton, and Charles S. Taber. 2013. The Rationalizing Voter. New York: Cambridge University Press.

Lovett, Mitchell J., and Michael Peress. 2010. Targeting Political Advertising on Television. SSRN Electronic Journal 10 (3). http:// doi.org/10.2139/ssrn.1649469.

McGhee, Eric, and John Sides. 2005. "Do Campaigns Drive Partisan Turnout?" Political Behavior 33: 313-33.

Mummolo, Jonathan, and Erik Peterson. 2018. "Improving the Interpretation of Fixed Effects Regression Results." Political Science Research and Methods 6 (4): 829-35.

Nickell, Stephen. 1981. "Biases in Dynamic Models with Fixed Effects." Econometrica 49 (6): 1417-26.

Patterson, Thomas E., and Robert D. McClure. 1972. The Unseeing Eye: The Myth of Television Power in National Politics. New York: G.P. Putnam's Sons.

Petty, Richard E., Joseph R. Priester, and Duane T. Wegener. 2014. "Cognitive Processes in Attitude Change." In Handbook of Social Cognition, 2nd edition, eds. Robert S. Wyer and Thomas K. Srull, 69-142. Hillsdale, NJ: Erlbaum

Ridout, Travis M., and Michael M. Franz. 2011. The Persuasive Power of Campaign Advertising. Philadelphia, PA: Temple University Press.

Ridout, Travis N., Erika Franklin Fowler, and Michael M. Franz. 2021. "The Influence of Goals and Timing: How Campaigns Deploy Ads on Facebook." Journal of Information Technology \& Politics 18 (3): 293-309.

Sahni, Navdeep S. 2016. "Advertising Spillovers: Evidence from Online Field Experiments and Implications for Returns on Advertising." Journal of Marketing Research 53 (3): 459-78.

Schuster, Steven Sprick. 2020. "Does Campaign Spending Affect Election Outcomes? New Evidence from Transaction-Level Disbursement Data." Journal of Politics 82 (4): 1502-15.

Sears, David O., and Rick Kosterman. 1994. "Mass Media and Political Persuasion." In Persuasion: Psychological Insights and Perspectives, eds. Sharon Shavitt and Timothy C. Brock, 251-78. Boston: Allyn \& Bacon.

Shapiro, Bradley T. 2018. "Positive Spillovers and Free Riding in Advertising of Prescription Pharmaceuticals: The Case of Antidepressants." Journal of Political Economy 126 (1): 381-437.

Shaw, Daron R. 2006. The Race to 270: The Electoral College and the Campaign Strategies of 2000 and 2004. Chicago: University of Chicago Press.

Sides, John, and Lynn Vavreck. 2013. The Gamble: Choice and Chance in the 2012 Presidential Election. Princeton, NJ: Princeton University Press.

Sides, John, Lynn Vavreck, and Christopher Warshaw. 2021. "Replication Data for: The Effect of Television Advertising in United States Elections." Harvard Dataverse. Dataset. https:// doi.org/10.7910/DVN/F8JXHR.

Sides, John, Michael Tesler, and Lynn Vavreck. 2018. Identity Crisis: The 2016 Presidential Campaign and the Battle for the Meaning of America. Princeton, NJ: Princeton University Press.

Sood, Gaurav. 2016. Geographic Information on Designated Media Markets [computer file]. Version V9. https://doi.org/10.7910/DVN/ IVXEHT.

Spenkuch, Jorg L., and David Toniatti. 2018. "Political Advertising and Election Results." Quarterly Journal of Economics 133 (4): 1981-2036.

Wang, Yanwen, Michael Lewis, and David A. Schweidel. 2018. "A Border Strategy Analysis of Ad Source and Message Tone in Senatorial Campaigns." Marketing Science 37 (3): 333-55.

Westlye, Mark Christopher. 1991. Senate Elections and Campaign Intensity. Baltimore, MD: Johns Hopkins University Press.

Zaller, John. 1992. The Nature and Origins of Mass Opinion. New York: Cambridge University Press. 